e-ISSN: 2721-3013, p-ISSN: 2721-3005

DOI: https://doi.org/10.38035/jafm.v1i4

Received: 10 Agust 2020, Revised: 23 Agust 2020, Publish: 17 September 2020 https://creativecommons.org/licenses/by/4.0/

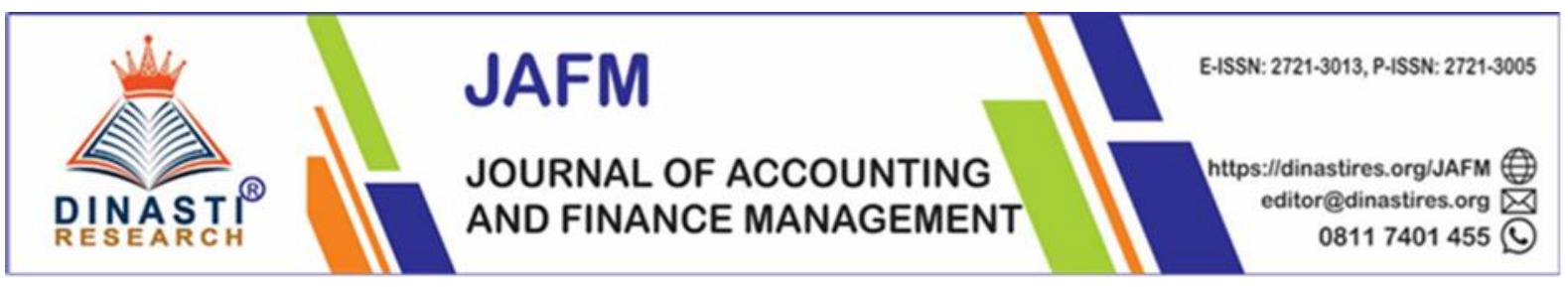

\title{
Analysis of Financial Performance Towards Firm Value (Case Study at Building Construction Sub Sectors on IDX During Period of 2012-2018)
}

\author{
Henry Broto Seno ${ }^{1 *}$, Hakiman Thamrin² \\ 1) Mercu Buana University, Jakarta, Indonesia, henry.b.seno@gmail.com \\ ${ }^{2)}$ Mercu Buana University, Jakarta, Indonesia, hakiman.thamrin@mercubuana.ac.id \\ *Corresponding Author: Henry Broto Seno ${ }^{1}$
}

\begin{abstract}
These research aims to find out those impact from capital structure, profitability, liquidity, activity and company size on firm value. The population in this research were building construction sub-sector companies which registered in Indonesia Stock Exchange during period 2012 till 2018. The samples were determined by purposive sampling technique. These data analysis method used was panel data regression analysis. The selected mode used Fixed Effect Model. The results showed that capital structure, profitability, liquidity, activity and company size simultaneously had an impact on company value. Partially it was found that capital structure and profitability had positive influence on company value, activity and company size had negative influence on company value, while liquidity had none impact towards company value. The most influential variable was profitability with coefficient value was 43.38 .
\end{abstract}

Keywords: Firm Value, Capital Structure, Profitability, Liquidity, Activity, Firm Size

\section{INTRODUCTION}

Infrastructure development is one of priority programs from President Joko Widodo and his Vice President Jusuf Kalla's Working Cabinet. Since 2015, the government has shifted subsidy spending into productive spending, such as infrastructure development, health and education. The infrastructure budget continues to increase from IDR 155 trillion in 2014 to IDR 410 trillion in 2018 (APBN). 


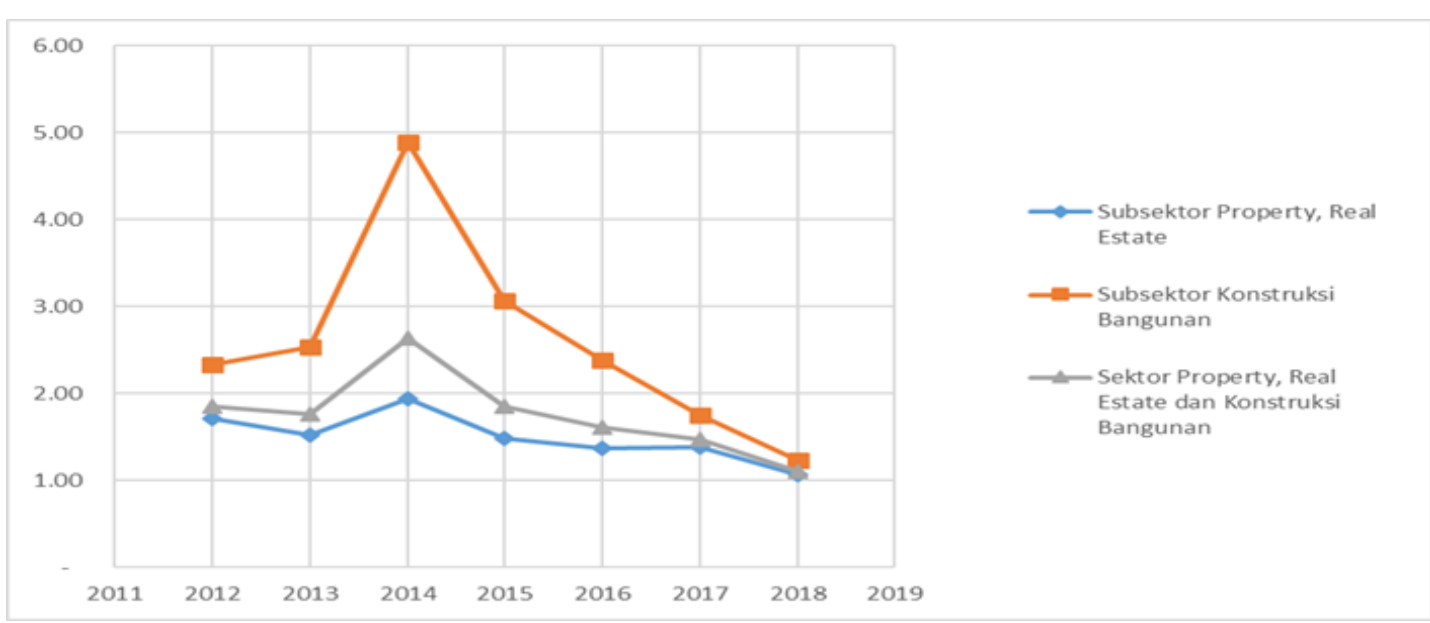

Figure 1. Price to Book Value (PBV) of Property, Real Estate and Building Construction Sectors

PBV value from property, real estate and building construction sectors had experienced fluctuated movements from 2012 till 2018. PBV value from building construction sub-sector appeared to be higher than PBV value from property, real estate and building construction sectors. Meanwhile, the PBV value on real estate property sub-sector was below than PBV value for property, real estate and building construction sectors. PBV value of building construction sub-sector had experienced an significant increase in 2014. However, from 2014 till 2018 amidst the increasing of infrastructure budget and rapid infrastructure development and the PBV value from building construction sub-sector continued to decline and it approach the PBV value from property, real estate and building construction sectors also PBV value from property subsector, real estate.

Companies are required to discovered the optimal capital structure policy because it fundamentally that this sources of funding had impact on firm value Wild et al (2005) which defined that capital structure is composition from funding between self-financing (equity) and debt. The higher proportion of debt, the higher share price and it would reflects on the higher firm value. However, at certain point, the increasing in debt will reduce the value from company because the benefits which earned from using debt are less than the costs incurred. The right funding decision will increase the company ability in order to carried out company's operational activities.

Debt policy needs to be supported by company' ability to earned profits. The purpose of shareholders to invested their shares was to get an income in return. The higher company's ability to earned profits, the greater return that expected by investors. Therefore, the companies with high profitability will attracted the investors. Profitability had influence towards firm value.

A high liquidity value reflects a company's high ability to meet its short-term obligations. High liquidity shows the strength of company in terms of its ability to meet current debts from its current assets, so it would increase the confidence from outsiders towards company. Conversely, liquidity which is too high were also not good, because it shows that large number of idle funds which in turn could reduce the company's profitability. Sondakh (2019) shows that liquidity had significant positive impact on firm value. This result was contradicts with research by Hasania et al (2016), Utami and Welas (2017) which stated that liquidity had significant negative impact on firm value.

Research that carried out by Nurhayati (2013) and Putu et al. (2014) which have concluded that the company size had positive and significant influence on firm value. Different results were shown by Dada and Ghazali (2016) which explained that company size had significant negative impact towards firm Value. 
Based on the description above, it was known that these research had purpose to determine those influence from capital structure, profitability, liquidity, activity and company size against firm value.

\section{LITERATURE REVIEW \\ Modigliani-Miller Theory}

According to Modigliani and Miller (1963), when there has a tax, the funding decision becomes relevant. It because in general, the interest which paid could be used to reduce tax deductable income. Modigliani and Miller argues that firm value which use debt will be greater than the firm value which not use debt.

\section{Pecking Order Theory}

Tendency of companies to determine the choice of funding sources based on hierarchy of risks. This theory stated that companies preffered those internal financing (funding from the company's operations in the form of retained earnings). If external financing was required, then company will issue the safest securities first, such as starting with the issuance of bonds then following by securities with option characteristics, and finally if its not sufficient, the new shares would be issued. Internal funds are preferred over external funds because internal funds will allows companies to no longer need to seek loans from outside parties. External funds are preferred in the form of debt rather than equity.

\section{Company Value}

Salvatore (2005) stated that the main purpose of the company based on theory of the firm was to maximized those wealth or value from company (firm value) Maximizing the company value is very important, because it was also means by maximizing the prosperity of shareholders, which is the main goal of the company.

\section{Capital Structure}

Modigliani and Miller developed a theory by showing that debt is beneficial because interest could be tax deductible (tax savings benefit), but debt also incurs costs related to potential bankruptcy. According to this statement the optimal capital structure should be in balance between tax benefits of debt and bankruptcy costs. The trade-off model could predicts which company maintains an optimal capital structure where the marginal benefit of debt equals to the marginal cost incurred. The trade-off model could predicted if in searching connection between capital structure and firm value there has an optimal level of leverage inside.

\section{Research Hypothesis}

Ha1: Debt to Equity Ratio (DER) had positive influence on Price to Book Value (PBV)

Ha2: Return on Assets (ROA) had positive impact on Price to Book Value (PBV)

Ha3: Current ratio (CR) had negative influence on Price to Book Value (PBV)

Ha4: Total Asset Turnover (TATO) had negative impact on Price to Book Value (PBV)

Ha5: Company size had negative impact on Price to Book Value (PBV)

\section{RESEARCH METHODS}

The data used were company's financial statements during these research period, from 2012 to 2018. The sample was choosen by purposive sampling technique then it Obtained 7 companies as research samples such as in belows: 
Table 1. Research Sample

\begin{tabular}{cll}
\hline No & Code & \multicolumn{1}{c}{ Name } \\
\hline 1 & ADHI & Adhi Karya (Persero) Tbk. \\
2 & DGIK & Nusa Konstruksi Enjiniring Tbk \\
3 & JKON & Jaya Konstruksi Manggala Pratama Tbk \\
4 & PTPP & PP (Persero) Tbk. \\
5 & TOTL & Total Bangun Persada Tbk. \\
6 & WIKA & Wijaya Karya (Persero) Tbk. \\
7 & WSKT & Waskita Karya (Persero) Tbk. \\
\hline
\end{tabular}

\section{FINDINGS AND DISCUSSION \\ DER Variable Descriptive Statistics}

Table 2. Descriptive Statistics of DER Variables

\begin{tabular}{lccccccc}
\hline \hline & TH_2012 & TH_2013 & TH_2014 & TH_2015 & TH_2016 & TH_2017 & TH_2018 \\
\hline \hline Mean & 2.233357 & 2.340986 & 2.371986 & 1.746314 & 1.542343 & 1.867643 & 1.985657 \\
Maximum & 4.164000 & 5.384100 & 5.243900 & 2.728800 & 2.660000 & 3.300000 & 3.310000 \\
Minimum & 0.750000 & 0.980000 & 0.850000 & 0.600000 & 0.780000 & 0.750000 & 0.860000 \\
Std. Dev. & 1.305996 & 1.594823 & 1.556239 & 0.887225 & 0.715551 & 0.813305 & 0.793867
\end{tabular}

During these research period, the lowest DER value occurred in 2015 which valued at 0.600000 at PT Adhi Karya (Persero) Tbk (ADHI). Meanwhile, the highest DER value occurred in 2013 amounted to 5,384100 at PT Pembangunan Perumahan (Persero) Tbk (PTPP). The lowest standard deviation value occurred in 2016. The highest average (mean) DER value occurred in 2014 which had an influence on the highest PBV mean value that occurred in the same year.

\section{ROA Descriptive Statistics}

Table 3. Descriptive Statistics of ROA Variables

\begin{tabular}{lccccccc}
\hline \hline & TH_2012 & TH_2013 & TH_2014 & TH_2015 & TH_2016 & TH_2017 & TH_2018 \\
\hline \hline Mean & 0.050304 & 0.054522 & 0.049048 & 0.047486 & 0.008966 & 0.044779 & 0.040719 \\
Maximum & 0.085100 & 0.087300 & 0.066600 & 0.071700 & 0.082762 & 0.075400 & 0.064600 \\
Minimum & 0.027000 & 0.031500 & 0.029900 & 0.002200 & -0.248800 & 0.005200 & 0.008500 \\
Std. Dev. & 0.021640 & 0.020117 & 0.012729 & 0.023879 & 0.115503 & 0.024377 & 0.017604
\end{tabular}

During the study period, the lowest ROA value occurred in 2016 valued at -0.248800 at PT Nusa Konstruksi Enjiniring Tbk (DGIK). Meanwhile, the highest ROA value occurred in 2013 valued at 0.087300 at PT Total Bangun Persada Tbk (TOTL). The lowest standard deviation value occurred in 2014. The lowest ROA value that occurred in 2016 had an influence on the lowest PBV value that occurred in the same year.

\section{CR Descriptive Statistics}

Table 4. CR Descriptive Statistics

\begin{tabular}{llllllll}
\hline \hline & TH_2012 & TH_2013 & TH_2014 & TH_2015 & TH_2016 & TH_2017 & TH_2018 \\
\hline \hline Mean & 1.392000 & 1.431800 & 1.379843 & 1.411986 & 1.394329 & 1.318986 & 1.330343 \\
Maximum & 1.778300 & 1.600000 & 1.654000 & 1.650000 & 1.690000 & 1.700000 & 1.541700 \\
Minimum & 1.101900 & 1.122500 & 1.205500 & 1.160000 & 1.170000 & 1.000000 & 1.164500 \\
Std. Dev. & 0.211024 & 0.170448 & 0.148597 & 0.206832 & 0.208439 & 0.235676 & 0.132027
\end{tabular}

During these research period, the lowest CR value occurred in 2017 valued was 1.0000 at PT Waskita Karya (Persero) Tbk (WSKT). Meanwhile, the highest CR value occurred in 2012 amounted to 1.7783 at PT Nusa Konstruksi Enjiniring Tbk (DGIK). The lowest standard deviation value occurred in 2012. The highest average (mean) CR occurred in 2013 and the lowest occurred in 2017, not related to PBV average. 


\section{TATO Descriptive Statistics}

Table 5. Descriptive Statistics of TATO Variables

\begin{tabular}{llllllll}
\hline & TH_2012 & TH_2013 & TH_2014 & TH_2015 & TH_2016 & TH_2017 & TH_2018 \\
\hline \hline Mean & 1.009881 & 1.005406 & 0.911226 & 0.762985 & 0.665367 & 0.677770 & 0.635749 \\
Maximum & 1.567776 & 1.344165 & 1.221316 & 1.221934 & 1.160592 & 1.069717 & 1.073478 \\
Minimum & 0.691967 & 0.691598 & 0.818751 & 0.466947 & 0.387224 & 0.461847 & 0.392221 \\
Std. Dev. & 0.272920 & 0.196534 & 0.149785 & 0.230201 & 0.258512 & 0.225131 & 0.242519
\end{tabular}

During these research period, the lowest TATO value occurred in 2016 which had valued of 0.3872 at PT Waskita Karya (Persero) Tbk (WSKT). Meanwhile, the highest TATO value occurred in 2012 valued at 1.5678 at PT Jaya Konstruksi Manggala Pratama Tbk (JKON). The lowest standard deviation value occurred in 2014. The lowest average (mean) TATO occurred in 2018, the lowest PBV average (mean) value also occurred in the same year.

\section{SIZE Variable Descriptive Statistics}

Table 6. Descriptive Statistics of SIZE Variables

\begin{tabular}{lccccccc}
\hline \hline & TH_2012 & TH_2013 & TH_2014 & TH_2015 & TH_2016 & TH_2017 & TH_2018 \\
\hline \hline Mean & 29.19692 & 29.38378 & 29.53141 & 29.81453 & 30.04767 & 30.30154 & 30.42534 \\
Maximum & 30.03080 & 30.16432 & 30.40106 & 31.04247 & 31.74913 & 32.21492 & 32.45446 \\
Minimum & 28.19518 & 28.37334 & 28.34656 & 28.37032 & 28.07251 & 28.23030 & 28.17789 \\
Std. Dev. & 0.784755 & 0.800552 & 0.879897 & 1.097758 & 1.419134 & 1.560695 & 1.667974
\end{tabular}

During these research period, the lowest SIZE value occurred in 2016 was 28.0725 at PT Nusa Konstruksi Enjiniring Tbk (DGIK). Meanwhile, the highest SIZE value occurred in 2018 valued was 32.4545 at PT Waskita Karya (Persero) Tbk (WSKT). The lowest standard deviation value occurred in 2012. The highest average (mean) SIZE occurred in 2018 which had an impact on the lowest PBV mean value that occurred in the same year.

\section{Selected Model}

Table 7. Fixed Effect Model

Dependent Variable: PBV

Method: Panel Least Squares

Sample: 20122018

Periods included: 7

Cross-sections included: 7

Total panel (balanced) observations: 49

\begin{tabular}{crrrr}
\hline \hline Variable & Coefficient & Std. Error & t-Statistic & Prob. \\
\hline \hline DER & 0.861718 & 0.382604 & 2.252246 & 0.0303 \\
ROA & 43.38547 & 20.07173 & 2.161522 & 0.0372 \\
CR & 0.695307 & 1.407255 & 0.494088 & 0.6242 \\
TATO & -6.163889 & 2.465871 & -2.499681 & 0.0170 \\
SIZE & -2.057927 & 0.726465 & -2.832794 & 0.0074 \\
C & 64.04344 & 23.08350 & 2.774425 & 0.0086 \\
\hline \multicolumn{5}{c}{ Effects Specification } \\
\hline Cross-section fixed (dummy variables) & \\
\hline \hline R-squared & 0.575837 Mean dependent var & 2.595816 \\
Adjusted R-squared & 0.449735 S.D. dependent var & 1.868467 \\
S.E. of regression & 1.386026 Akaike info criterion & 3.699652 \\
Sum squared resid & 71.07951 Schwarz criterion & 4.162955 \\
Log likelihood & -78.64147 Hannan-Quinn criter. & 3.875428 \\
F-statistic & 4.566426 & Durbin-Watson stat & 1.737677 \\
Prob(F-statistic) & 0.000228 & \\
\hline \hline
\end{tabular}




\section{F-Test}

Seen from Table 7, it was known that the p-value of F-statistic was $0.000228<0.05$. Therefore it could be concluded that Debt to Equity Ratio, Return on Assets, Current Ratio, Total Asset Turnover and company size simultaneously had impact to Price Book Value of building construction sub-sector companies on Indonesia Stock Exchange during period 2012-2018.

\section{Coefficient of Determination $\left(\mathbf{R}^{2}\right)$}

$\mathrm{R}$-Squared value was 0.575837 . This means that independent variables in this research, which is Debt to Equity Ratio, Return on Assets, Current Ratio, Total Asset Turnover and company size together could explained the dependent variable, which is company value (Price to Book Value) amounted of $57.58 \%$, the remaining $42.42 \%$ Was explained by other variables outside these research model.

\section{t-Test}

Based on Table 7 it is known that:

1) The coefficient value of DER was 0.861718 with p-value from t-count was $0.0303<0.05$, then Ha1 was accepted.

2) The coefficient value of ROA was 43.38547 with p-value from t-count was $0.0372<0.05$, then $\mathrm{Ha} 2$ was accepted

3) The coefficient value of CR was 0.695307 with $p$-value from t-count was $0.6242>0.05$, then $\mathrm{Ha} 3$ was rejected.

4) The coefficient value of TATO was -6.163889 with p-value from t-count of $0.0170<0.05$, then $\mathrm{Ha} 4$ was accepted.

5) The coefficient value of SIZE was -2.057927 with p-value from t-count of $0.0074<0.05$, then Ha5 was accepted.

\section{Discussion}

\section{The Impact of Capital Structure on Firm Value}

Capital Structure (DER) had positive impact on firm value (PBV) in building construction sub-sector companies at IDX during period 2012-2018. If the company's debt rises and did not exceed the optimal point, company's decision to use debt as a source of financing provides positive signal to investors and able to increase company value. This according to Modigliani and Miller theory (1963) which stated that value of companies that use debt will be greater than the value of companies that did not use debt. An increase in debt could be perceived by investors or potential investors that the company is working on a largescale project, thereby will increasing the company value. The results from first hypothesis were in line with research conducted by Hoque et al. (2014), Adegnuba et al. (2016), Pioh et al. (2018), Hirdinis (2019) which stated that DER had significant positive impact on firm value. However, the results of this research were not according to the research by Didi Handoko (2016), Lubis et al. (2017), Sintyana and Artini (2019) which defined that DER had none impact on firm value.

\section{The Impact of Profitability on Firm Value}

Profitability (ROA) had positive impact on firm value (PBV) on building construction sub-sector companies at IDX during 2012-2018. This indicated that greater the profitability of the company, the more income that could be distributed to shareholders thus the expected firm value will be higher. Companies with high profitability will provide an indication of good prospects which could direct investors/potential investors to increase the demand for shares and increase company value. The results of these second hypothesis were in line with 
research conducted by Li-Ju Chen and Shun-Yu Chen (2011), Ajayi Oziombo Dada and Zahiruddin Ghazali (2016), Sintyana and Artini (2019)meaning that ROA had significant positive impact on firm value. However, the results from this research were contradict to research by Didy Handoko (2016), Hirdinis (2019) which defined that ROA has none impact on firm value.

\section{The Impact of Liquidity on Firm Value}

Liquidity (CR) had no impact on firm value (PBV) in building construction sub-sector companies at IDX during period 2012-2018 period. This occured because these investor when invested their funds did not see the current ratio. Current Ratio also shows the level of security of short-term creditors or company's ability to pay short-term debts. Agency theory stated that agent and principal have different goals, the company has the goal of increasing the liquidity ratio, but investors did not see the liquidity ratio when investing their funds. The results from these third hypothesis were in line with research conducted by Husna and Satria (2019), Nurhayati (2013) who concluded that Current Ratio (CR) had no influence on firm value. However, these research results were not according to research by Utami and Welas (2017), Hasania et al (2016) which stated that Current Ratio (CR) had significant negative impact on firm value.

\section{The Influence of Activities towards Firm Value}

Activity (TATO) had negative impact on firm value (PBV) in building construction sub-sector companies in IDX during period 2012-2018. This indicated that high total asset turnover actually reduces firm value. Infrastructure projects with long project durations and turn-key project payment schemes make slow turnover of total assets. Slow turnover of total assets signals to investors that company had good financial condition to work on a project and working in large-scale project. By implementing a project with a turn key payment scheme, the margin which company gets will be even greater, thus increasing the company's value. The results of fourth hypothesis were in line with research by Wati (2017), Kushartono and Nurhasanah (2018) which stated that TATO had significant negative impact on firm value. However, the results from research were not according to the research from Utami and Welas (2017) which stated that TATO had none impact on firm value.

\section{The Impact of Firm Size on Firm Value}

Company size had negative impact on firm value (PBV) in building construction subsector companies on the IDX during period 2012-2018. The size of the company could be seen from the company's total assets namely too large considered as negative signal for investors or potential investors. Investors want to invest in companies which have good prospects, regardless the size of the company. The size of company had negative impact on firm value because investors think that companies which have large total assets tend to set more retained earnings to be used as their capital, compared to distributing dividends to shareholders. Companies which retain profits rather than share them as dividends could impact their share price and their value of the company. The results from fifth hypothesis were in line with research conducted by Ajayi Oziombo Dada and Zahiruddin Ghazali (2016), Utomo and Christy (2017), Aang Munawar (2018) which defined the company size had significant negative impact on firm value. However, these results was contradict to research by Laksitaputri (2012), Cheryta et al. (2017) that explained if company size had none impact on firm value. 


\section{CONCLUSION AND SUGGESTION \\ Conclusion}

Based on these research results which has been done, these following conclusions were obtained as in belows:

1) Capital structure (Debt to Equity Ratio) had positive impact on firm value (Price to Book Value) in building construction sub-sector companies on Indonesia Stock Exchange during period 2012-2018.

2) Profitability (Return on Assets) had positive influence on firm value (Price to Book Value) in building construction sub-sector companies on Indonesia Stock Exchange during period 2012-2018.

3) Liquidity (Current Ratio) had none impact on firm value (Price to Book Value) in building construction sub-sector companies on Indonesia Stock Exchange during period 20122018.

4) Activity (Total Asset Turnover) had negative impact on firm value (Price to Book Value) in building construction sub-sector companies on Indonesia Stock Exchange during period 2012-2018.

5) Company size had negative impact on firm value (Price to Book Value) in building construction sub-sector companies on Indonesia Stock Exchange during period 20122018.

\section{Suggestion}

The following suggestions that could be given are:

1) Investors and potential investors who wish to invest in building construction sub-sector company on Indonesia Stock Exchange should pay attention to Debt to Equity Ratio (DER), Return on Assets (ROA), Total Asset Turnover (TATO) and company size that significantly influence towards company value.

2) Those Companies in building construction sub-sector need to improve their performance in managing their debt policies in order to contribute in increasing company value. Management should improve its capabilities in managing the debt policies so the company's capital structure did not reach its optimal point. In other words, management need to maintain the composition between total debt and total equity which owned by shareholders.

3) An increase in company assets should be followed by increasing in profitability. Because large company assets without increasing profitability will reduce its firm value.

4) Building construction companies should be strengthen by engineering division in order to generate optimum profit while doing a project. This because each different work item will generates a different profit, maybe even loss. High sales should be followed by high profits.

\section{REFERENCES}

Agustina, N. and Nazir (2018) 'Pengaruh Firm Size, DER, ROA dan Current Asset Terhadap Price Value pada Perusahaan Manufaktur Sub Sektor Tekstil di Indonesia', Jurnal Visioner \& Strategis, 7(2), pp. 43-49.

Ang, R. (1997), Buku Pintar Pasar Modal Indonesia, Jakarta: Mediasoft Indonesia.

Brigham, F. dan Houston, J. (2001) Manajemen Keuangan, Edisi Kedelapan, Jakarta: Erlangga.

Brigham, F. and Gapenski, L. (1996) Financial Management Theory and Practise, Fifth Edition, United State of America.

Fama, E. F. (1978) 'The Effect of a Firm's Investment and Financing Decision on the Welfare of its Security Holders', American Economic Review, vol 68, pp 272-28. 
Gujarati, D. (2003) Ekonometrika Dasar, Jakarta: Erlangga.

Gulo (2010) Metodologi Penelitian, Jakarta: Grasindo.

Hestinoviana, V., Suhadak and Handayani, S. R. (2013) 'The Influence Of Profitability, Solvability, Asset Growth, And Sales Growth Toward Firm Value', Faculty of Administrative Science Brawijaya University.

Hirdinis, M. (2019) 'Capital structure and firm size on firm value moderated by profitability', International Journal of Economics and Business Administration, 7(1), pp. 174-191.

Husnan, S. (2001) Manajemen Keuangan Teori Dan Penerapan (Keputusan Jangka Pendek), Yogyakarta: BPFE.Modigliani, F. and Miller (1958) The Cost of Capital, Corporate Finance and the Theory of Investment, The American Economics Review, Vol. XIVIII. No. 3, pp. 261-297.

Myers, S. C. (1984) 'The Capital Structure Puzzle', Journal of Finance, 39(3), pp. 575-592.

Myers, S. C. and Majluf, N. S. (1984) 'Corporate Financing and Investment Decisions When Firms have Information that Investors do not have' The Journal of Financial Economics, 13,pp 187-221

Salvatore, D. (2005) Managerial Economics, Singapore: Thomson Learning.

Sihombing, P. (2018) Corporate Financial Management, IPB Press Bogor.

Van Horne, J. C. dan Wachowicz, J. M. (2012) Prinsip-Prinsip Manajemen Keuangan, Jakarta: Salemba Empat. 